\title{
Connessioni figurative e informative tra lo spazio costruito e lo spazio pittorico
}

\author{
Rachele Angela Bernardello \\ Andrea Momolo
}

Abstract

La relazione fisico-figurativa tra spazio costruito e pittorico architettonico è un tema della rappresentazione da sempre esplorato per poter cogliere i più complessi aspetti teorici e tecnici dei maestri del quadraturismo. Un approccio innovativo a questi scenari è consentito dall'applicazione di processi di modellazione BIM. La possibilità, infatti, di allacciare in un'unica piattaforma digitale strutture figurative e informative differenti, esplicitandone le relazioni fisiche tramite una struttura gerarchica di dati e aumentando l'esperienza immersiva con operazioni di restituzione prospettica e strumenti per la fruizione virtuale, garantisce di aumentare le esperienze che sempre convivono nel patrimonio culturale: quella dei fruitori e degli stessi studiosi.

Questo flusso di ricerca, implementato a Villa Selvatico a Battaglia Terme, ha permesso di definire le realtà costruita e dipinta, interrogabili sia per poter programmare attività di conservazione e gestione, sia per avviare un percorso di valorizzazione in ottica turistica. In particolare, il metodo di restituzione digitale Scan-to-BIM garantisce di ricostruire il legame esistente tra architettura e spazio pittorico, relazionando i diversi elementi semantici in termini spaziali e funzionali.

Infine, la struttura informativa adottata ha dimostrato di poter dialogare con tecniche di visualizzazione interattive come la VR, esplorando nuovi linguaggi per comunicare la conoscenza, particolarmente efficaci in questo periodo in cui le distanze dal mondo culturale si sono fatte fisiche.

Parole chiave

BIM, restituzione prospettica, realtà virtuaòe, scan-to-BIM, spazio immersivo.

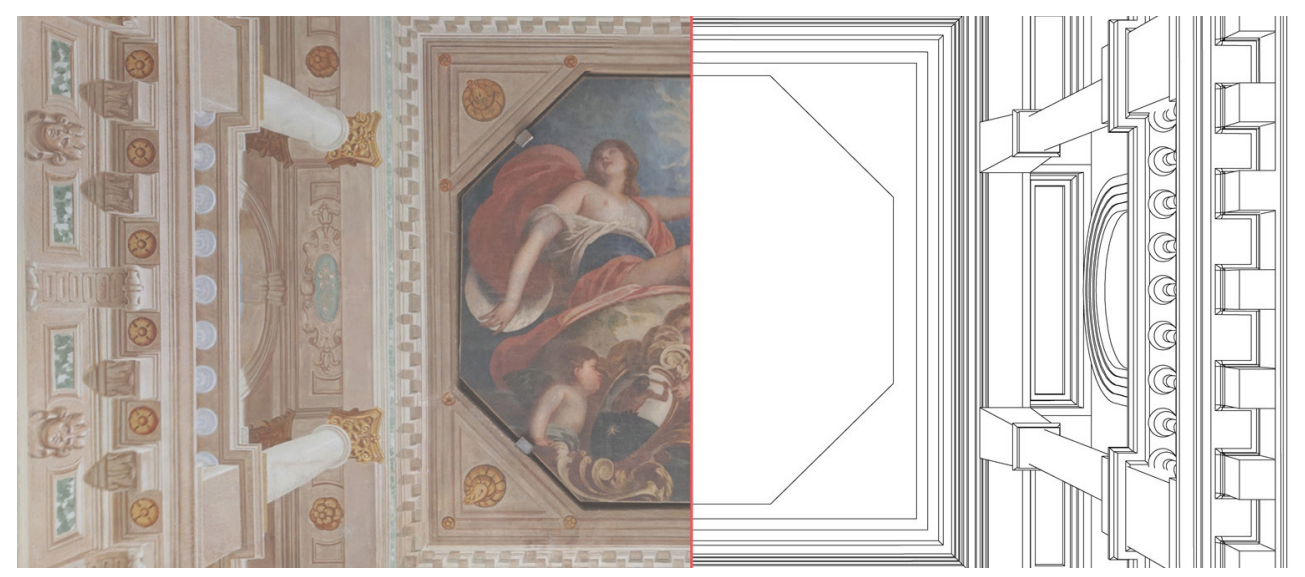




\section{Processi Scan-to-BIM per la restituzione informativa dello spazio}

I metodi per la conservazione e la valorizzazione del patrimonio storico, che si avvalgono di processi di digitalizzazione ed elaborazione dei dati, consentono la definizione e la sperimentazione di percorsi tecnico scientifici per gli operatori del settore e allo stesso tempo cognitivi ed emozionali per i fruitori.

Una declinazione particolare di questo processo culturale riguarda spazi interni impreziositi da affreschi di quadraturismo barocco che, per loro natura, esaltano una connessione profonda tra lo spazio architettonico fisico, reale e tangibile, con lo spazio pittorico, governabile sul piano e solamente osservabile. La natura generativa caratterizzata dal dinamico intreccio tra arte e scienza di questo genere pittorico [Migliari 20 I 4, pp. I-4] si sviluppa necessariamente verso un approccio organizzato e multidisciplinare. Per questa ragione, negli ultimi decenni, le quadrature e gli edifici storici che le accolgono, sono diventati laboratori stimolanti per una serie di figure professionali: studiosi della scienza della rappresentazione, architetti, ingegneri, nonché storici dell'arte e dell'architettura.

Inoltre, lo sviluppo tecnologico e la sperimentazione procedurale dimostrano sempre più quanto vi sia la possibilità di coordinare, tramite gli strumenti della rappresentazione digitale, scopi e intenzioni differenti, garantendo il coordinamento e la prosecuzione di attività parallele sul medesimo manufatto tramite l'organizzazione di piattaforme collaborative.

Questa pluralità all'interno di uno stesso modello digitale è assicurata dall'implementazione del Building Information Modeling (BIM): come processo operativo, esso risulta essere l'ambiente informativo ideale in cui poter esprimere usi diversi del modello, integrare la dimensione architettonica con quella pittorica, progettare esperienze virtuali conoscitive turistico-museali [Giordano et al. 2019].

L'esperienza su Villa Selvatico, a Battaglia Terme, esplicita questo flusso di lavoro 'virtuoso', secondo le fasi sopracitate: il rilievo digitale del manufatto, l'elaborazione dei dati e la produzione di un modello informativo, la restituzione prospettica della superficie pittorica, la programmazione di un percorso multimediale di valorizzazione.

L'interessante condizione architettonica, storica e gestionale di Villa Selvatico è un esempio sostanziale nell'implementazione della metodologia BIM based volta alla definizione di scenari di gestione e valorizzazione del patrimonio basati sulla riconnessione, in un ambiente virtuale, dello spazio dipinto e dello spazio costruito. Si tratta di una villa veneta del XVII secolo che gode di una posizione paesaggistica di pregio, ai piedi dei Colli Euganei (fig. I).

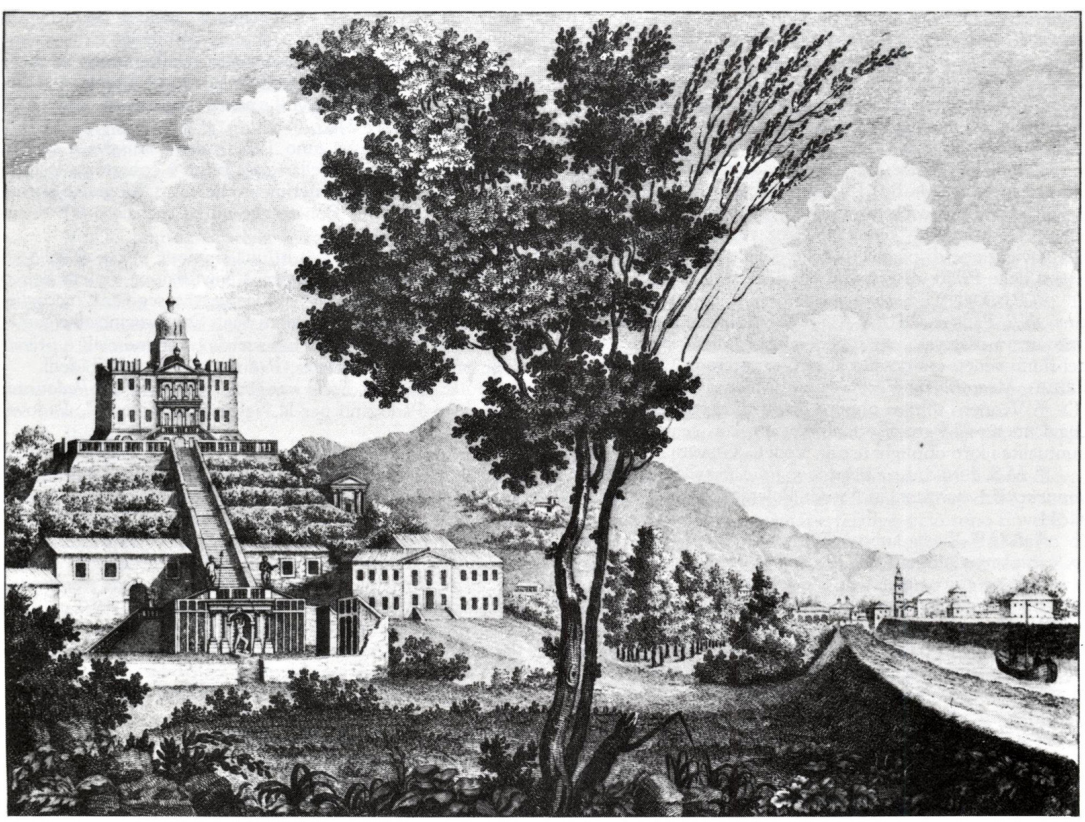


Di notevole valore artistico per i cicli pittorici che ne impreziosiscono le sale - tra cui degli interessanti esempi di Quadraturismo barocco, la Villa è un luogo d'eccezione dove spazio architettonico e spazio pittorico si connettono profondamente (fig. 2).

L'intento di migliorare l'esperienza dell'utente e dei professionisti su ambienti digitali diversi sfruttando più strumenti, ma riferendosi al medesimo oggetto informativo, consente di garantire una stretta relazione tra il clone digitale degli elementi architettonici con gli affreschi e le loro elaborazioni digitali. A partire da un'iniziale definizione degli usi del modello e degli scopi del processo di restituzione informativa, identificabili nel processo rilievo/rappresentazione in collegamento ed estensione [Succar 2020], è stato possibile procedere con la modellazione BIM, basata su un rilievo digitale 2D svolto in occasione di un restauro del 2005, integrato con un rilievo fotogrammetrico dei principali spazi interni affrescati. L'impego di metodologie diverse di acquisizione a seconda delle necessità da soddisfare durante e al termine dell'intero processo è determinato da una matrice di valori che risponde a fattori multidisciplinari, tra cui la conformazione geometrica-architettonica e l'output finale.

II modello BIM diventa contenitore di informazioni tecniche a disposizione per figure professionali, nonché potente veicolo di divulgazione dell'edificio storico stesso e dei relativi apparati figurativi, offrendo una duplice utilità che sempre emerge nell'ambito di architetture di pregio [Logothetis et al. 20 I5, pp. 177- I83].Tra i benefici che l'impiego del BIM moltiplica in riferimento al patrimonio esistente di pregio, si è voluto dimostrare come esso possa non solo gestire e documentare l'edificio storico, ma anche comunicare e divulgare il patrimonio culturale, interagendo con nuove tecnologie e sperimentando metodi di rappresentazione innovativi [De Rosa et al. 2020, pp. 21 9-227, Brumana et al. 2013, pp. 497-504].

La modellazione parametrica dello spazio dell'architettura reale si è affiancata a quella dello spazio pittorico rappresentato negli affreschi a trompe-l'oeil. Le due realtà sono accomunate anche da processi generativi di restituzione: così come il modello della Villa si basa sul metodo Scan-To-BIM, partendo dagli elaborati di un rilievo digitale, anche quello dell'ambiente pittorico si basa su un processo di restituzione geometrica capace di riprodurre in uno spazio tridimensionale virtuale le architetture rappresentate in prospettiva.

La possibilità di connettere nel modello BIM le informazioni proprie veicolate dagli output del rilievo, come la nuvola di punti dello spazio reale e le ortofoto dello spazio dipinto, con

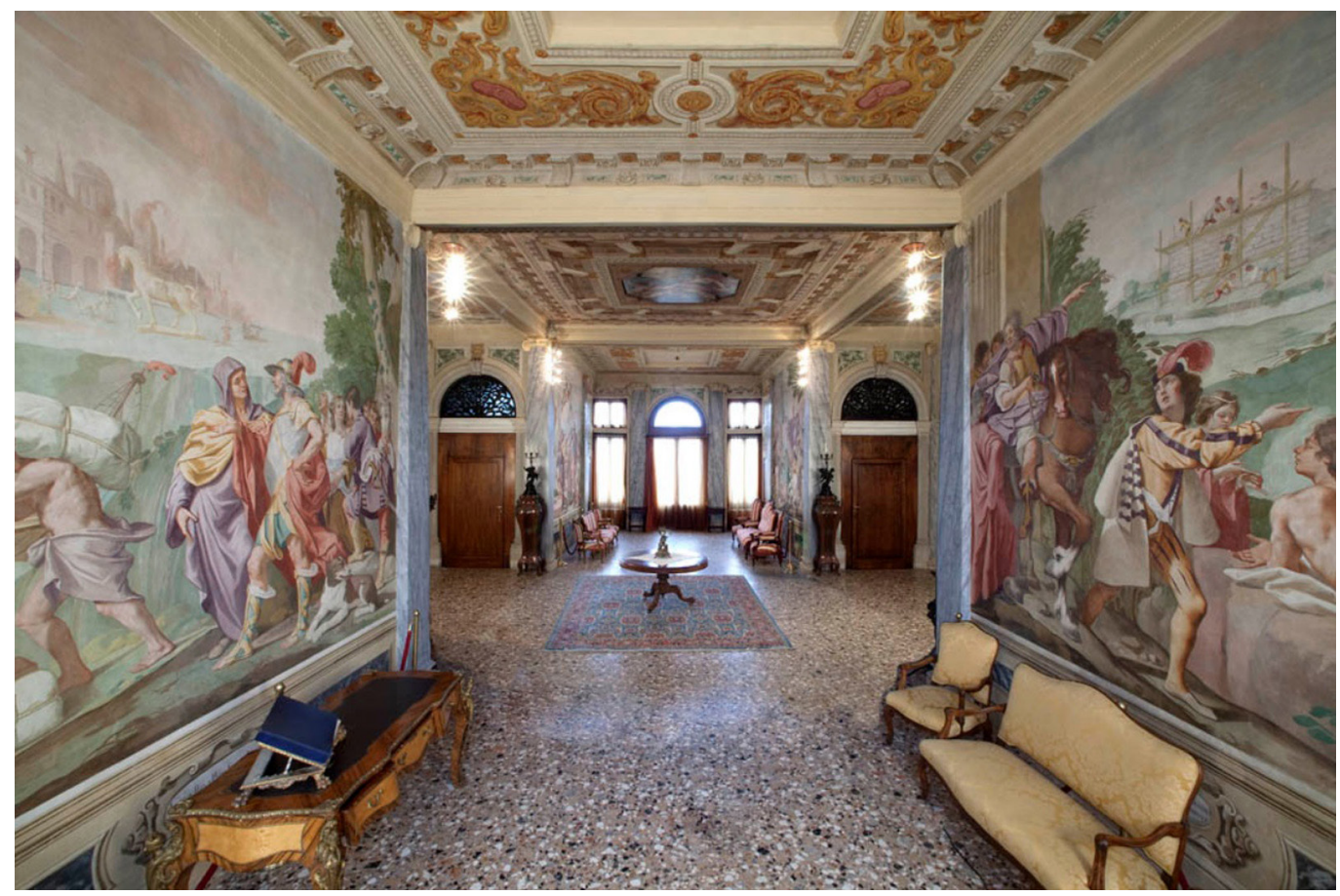


gli oggetti digitali informativi definisce il nodo cruciale di questa attività di ricerca che si esprime nella sua completezza nell'ultima fase di questo processo [Giordano et al. 20 I8], owero la condivisione di una ricostruzione digitale integrata che permette di immergersi non solo nella realtà della Villa storica, ma anche negli spazi virtuali disegnati con maestria e conoscenza tecnico-geometrica da artisti vissuti più di 400 anni fa.

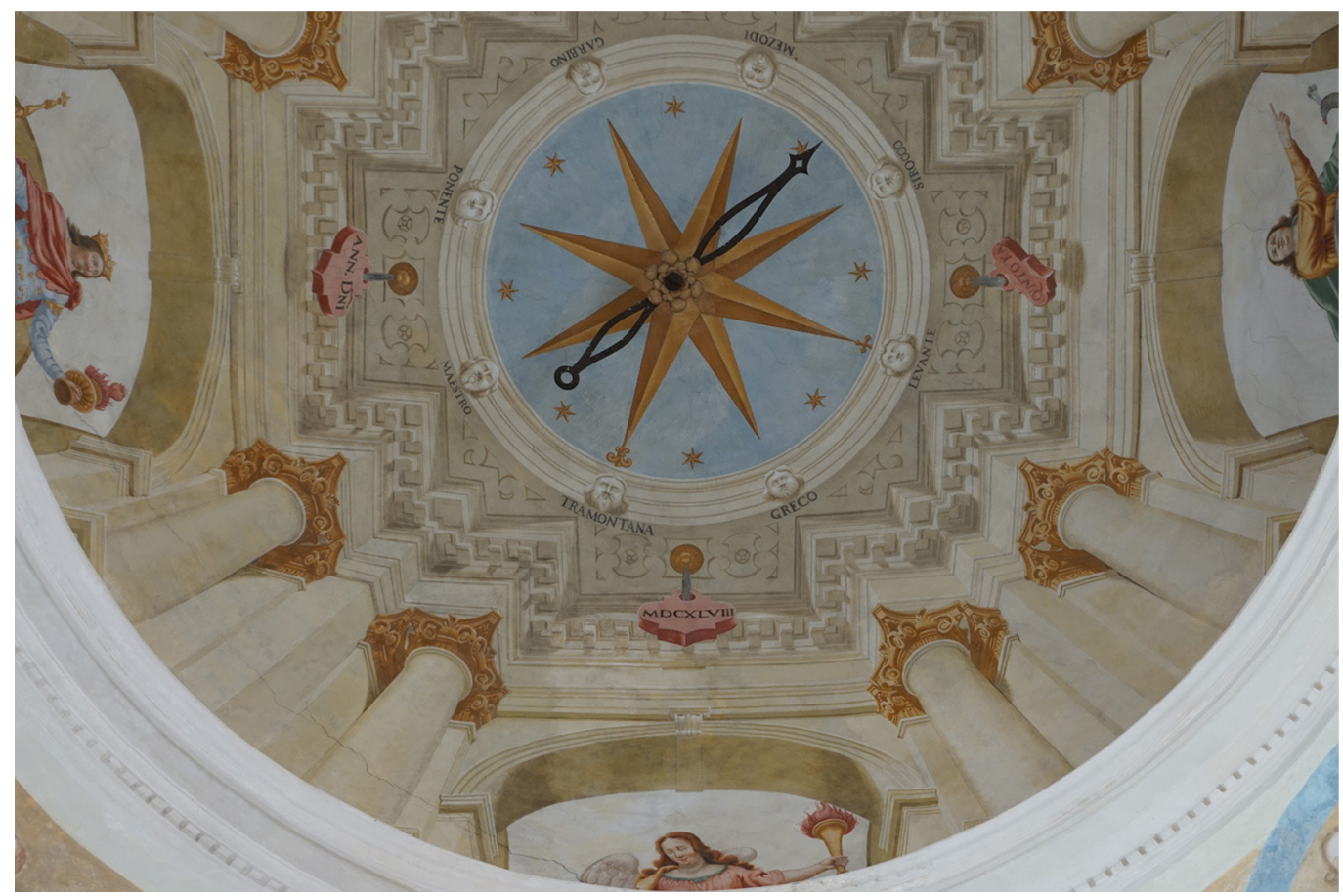

\section{La restituzione prospettica di un'architettura dipinta}

"Qualsiasi prospettiva architettonica, su tela o su muro, è un'illusione prospettica. Finge un'architettura 'che non c'è'.

[Fasolo 1992, p. 83]

Inizia così un saggio del 1992 in cui Fasolo suggerisce una classificazione delle prospettive architettoniche in base al preciso rapporto che esse instaurano con l'architettura reale.

Definisce di primo grado quelle in cui non vi è uno stretto legame tra spazio reale e spazio rappresentato, distinguendole da quelle di secondo grado che, al contrario, sono studiate ad hoc per creare una prosecuzione illusoria fra architettura immaginaria e architettura vera. L'apparato pittorico ha assunto così un ruolo centrale nell'iter di ricostruzione e rappresentazione digitale di Villa Selvatico.

Nel 1658, il complesso era arrivato a ospitare una pinacoteca, con tele e opere di alcuni degli artisti più influenti dell'epoca [Fantelli 1989, pp. 95-100], di cui oggi rimangono i cicli di affreschi che, restaurati di recente, adornano interamente il salone cruciforme al primo piano e la cupola del piano superiore.

La paternità artistica di questi ambienti appartiene a due pittori reggiani, i quali tra il 1647 e il 1650 hanno lavorato congiuntamente dividendosi i soggetti in base alla loro tipologia: Lorenzo Bedogni lavorando principalmente come pittore di architetture, dipingendo il finto colonnato all'interno della cupola (fig. 3) e una serie di quadrature prospettiche al piano inferiore; Luca Ferrari, che ha raffigurato sulle pareti dei bracci lunghi della sala quattro episodi del mito di Antenore (fig. 4) [Brunelli et al I931, Fantelli 1989, pp. 95- 100]. Questi ultimi, pur rappresentando degli interessanti esempi di pittura barocca, ma non avendo al loro interno 


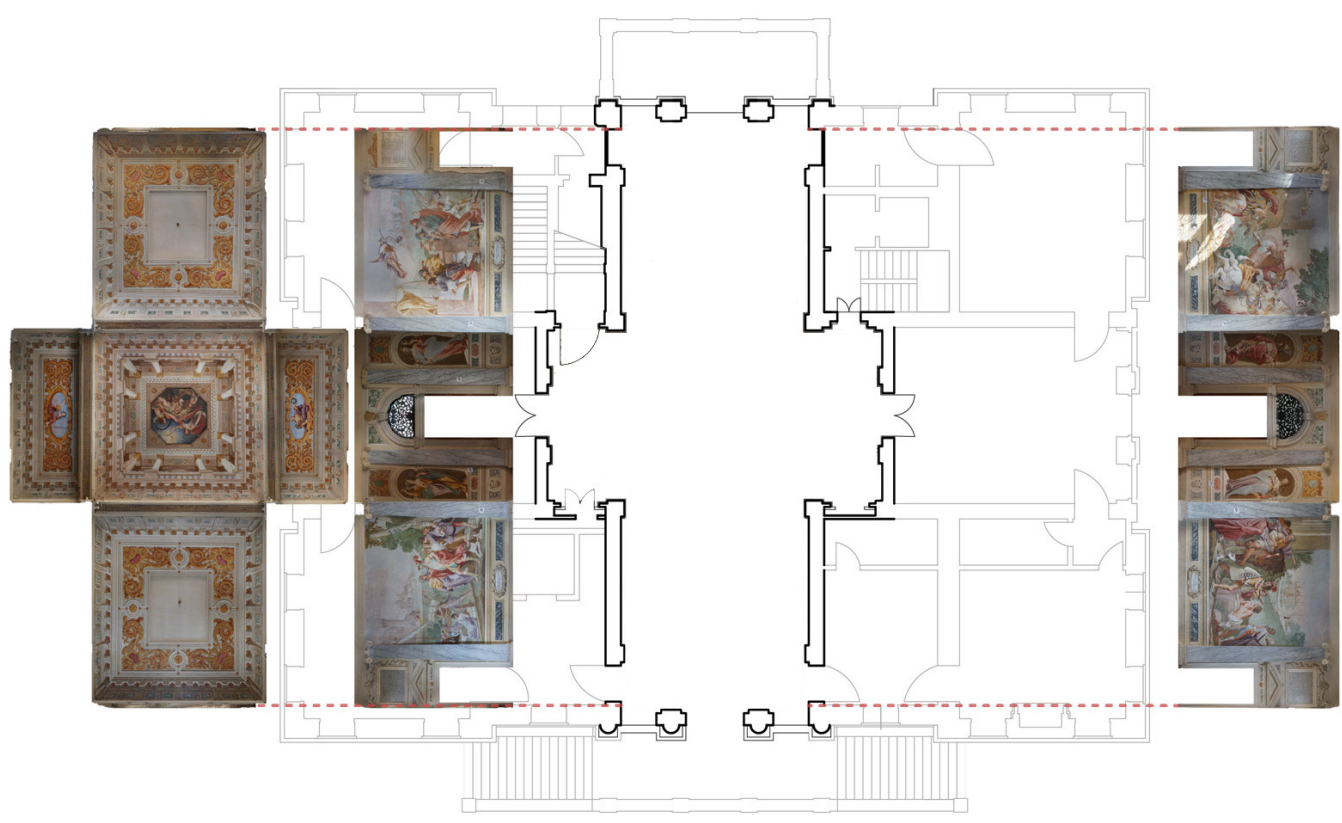

dei riferimenti architettonici sostanziali, non sono stati oggetto di restituzione prospettica, ma semplicemente mappati e catalogati all'interno del modello BIM.

Maggiore attenzione è stata invece posta sulle quadrature prospettiche in cui è evidente l'esistenza di un rapporto stretto, limpido e diretto tra dipinto e architettura. Si è voluto quindi indagare questa connessione ideale e successivamente rappresentarla virtualmente a partire dall'applicazione della restituzione prospettica. In questo modo, facendo dialogare la tradizione con strumenti tecnologici innovativi, è stato possibile ricreare lo spazio architettonico dipinto da Bedogni, dando così una forma, seppur virtuale, al forte legame che lui stesso aveva voluto instaurare tra rappresentazione pittorica e spazialità architettonica (fig. 5).

La parte centrale del soffitto della sala al piano primo, risulta la quadratura più completa, sia per la complessità della scena architettonica rappresentata sia per l'efficacia illusoria. Le operazioni di restituzione sono state eseguite utilizzando l'ortofoto elaborata dal rilievo fotogrammetrico. La scena dipinta è doppiamente simmetrica, scandita da una serie di elementi che simulano lo sfondamento del piano superiore, componendo un loggiato a pianta quadrata scandito da colonne e pilastri corinzi. Al di sopra della cornice aggettante in primo piano, si imposta l'ipotetico piano di calpestio della loggia, suddivisa da quattro pilastri agli angoli e due colonne per lato, tutti di ordine corinzio. Questi poggiano su dei massicci basamenti che scandiscono a loro volta il parapetto balaustrato. Infine, la prospettiva architettonica si chiude con un soffitto decorato e scavato al centro da un ottagono che ospita la pala del Padovanino raffigurante La gloria di casa Selvatico.

II punto principale si è trovato estendendo tutte le rette prospettiche ortogonali al quadro, le quali convergono esattamente nel punto centrale del dipinto, confermando una prospettiva monocentrica. Dopo una fase di studio del riferimento prospettico applicato dall'artista, si è passati alla ricostruzione della scena pittorica nella sua tridimensionalità [Sgrosso 1979] e alla sua ricollocazione all'interno di una nuova realtà spaziale strettamente connessa con la sua copia digitale in ambiente BIM (fig. 6). Una volta posizionato correttamente, la coesistenza tridimensionale dei due modelli ha permesso di indagare le caratteristiche dello spazio dipinto e di fare alcune considerazioni riguardo l'impianto architettonico e prospettico immaginato dal pittore, integrando lo spazio rappresentato come un oggetto informativo nel modello BIM.

Come è possibile osservare dalla sezione (fig. 7), la distanza principale determinata con la restituzione prospettica è di $5,90 \mathrm{~m}$, di gran lunga maggiore rispetto alla reale distanza tra il piano pittorico e l'occhio dell'osservatore (circa 3,20m). II che implica che l'osservatore 
Fig. 5. Immagine

dell'ortofoto confrontata

con lo spazio pittorico

ricostruito virtualmente.

Fig. 6. Restituzione

prospettica di piant

e sezione dello spazio

dipinto.
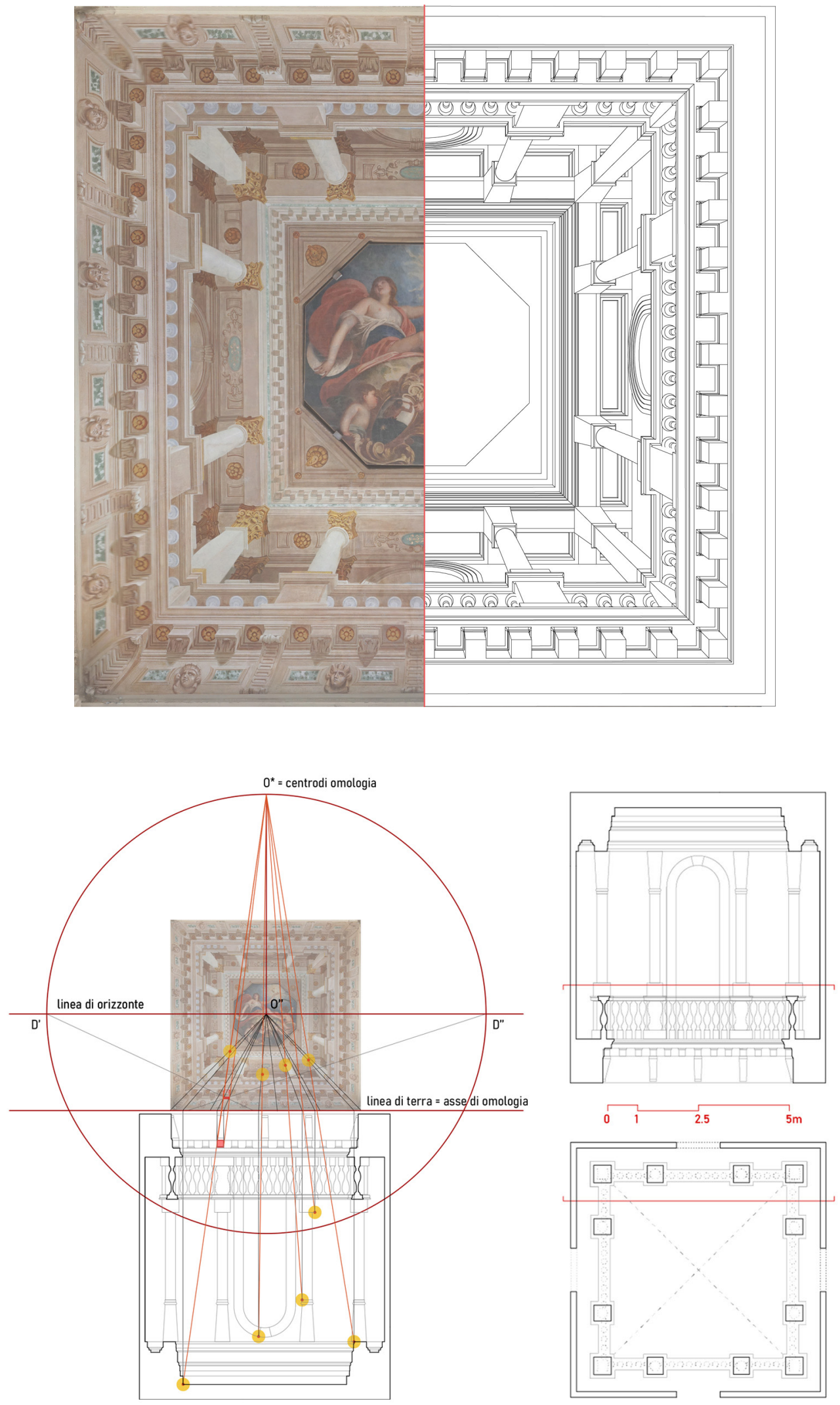
ideale è posizionato al di fuori dello spazio della sala affrescata e precisamente Im al di sotto del piano di calpestio. Rapportando gli elementi dello spazio dipinto con quelli reali, si sono notate delle significative incongruenze e dei sovradimensionamenti notevoli, il ché ha contribuito a svelare alcune aberrazioni prospettiche, che tuttavia non sono da considerarsi come errori, ma come accorgimenti studiati dal quadraturista per far fronte alla ridotta altezza dei vani in rapporto alle dimensioni del costrutto virtuale [Bertocci et al. 2020, pp. I38- I40]. In questo modo la percezione dello spazio dipinto è corretta ad hoc, per essere apprezzata da un punto di vista più ravvicinato rispetto a quello teorico, comportando però la creazione di uno spazio ideale con dimensioni ai limiti della vivibilità, che stridono con la scala umana.

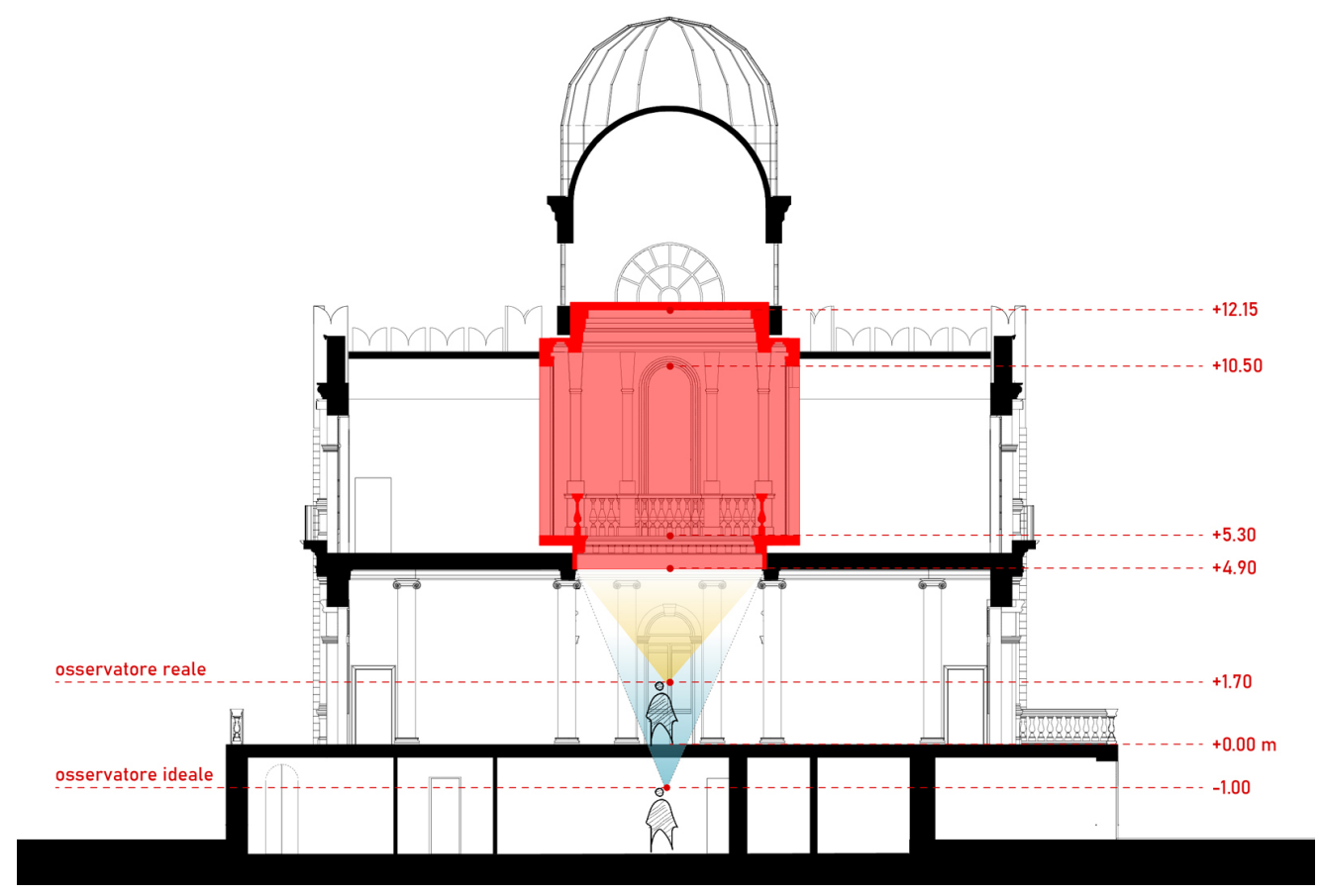

Tecniche e linguaggi per comunicare il bene culturale

Nell'ultima fase di ricerca, si è posta particolare attenzione sulle nuove tecnologie introdotte nel campo della rappresentazione e sulle relazioni che si possono instaurare tra queste e il modello BIM. Riconosciuta la promettente capacità del BIM come processo in grado di espandere le potenzialità del linguaggio del Disegno verso un ambito digitale, [Garagnani 20 I 4, pp. 357-369] si è deciso di appoggiarsi alla rappresentazione virtuale per tradurre analisi ed elaborazioni effettuate in ricostruzioni 3D multimediali, facilmente condivisibili su piattaforme online.

Questa scelta assume un valore non banale nel particolare attuale momento storico, caratterizzato dalla necessità sanitaria di mantenere le distanze, non solo interpersonali, ma anche dai luoghi di cultura. È evidentemente il ruolo sempre più centrale dell'innovazione tecnologica come soluzione potenzialmente in grado di abbattere le barriere fisiche che stanno mettendo in ginocchio settori essenziali come questo [Colombo et al. 2020, pp. 95- I 02].

Al fine di attrarre turisti e promuovere il patrimonio culturale, emerge anche la necessità di coinvolgere emotivamente i visitatori, di adottare una prospettiva utente-centrica [Marasco et al. 20 I9, pp. 426-443], considerando lo spazio virtuale non solo in funzione di quello fisico, ma soprattutto come opportunità per offrire una nuova tipologia di esperienza [Champion 2019, King et al. 2016, pp. 76-10I]. 
Fig. 8. Confronto di due viste acquisite dallo stesso punto di osservazione. A sinistra e possibile vedere lo spazio pittorico implementato nella Villa in modalità concettuale; a destra lo spazio architettonico.

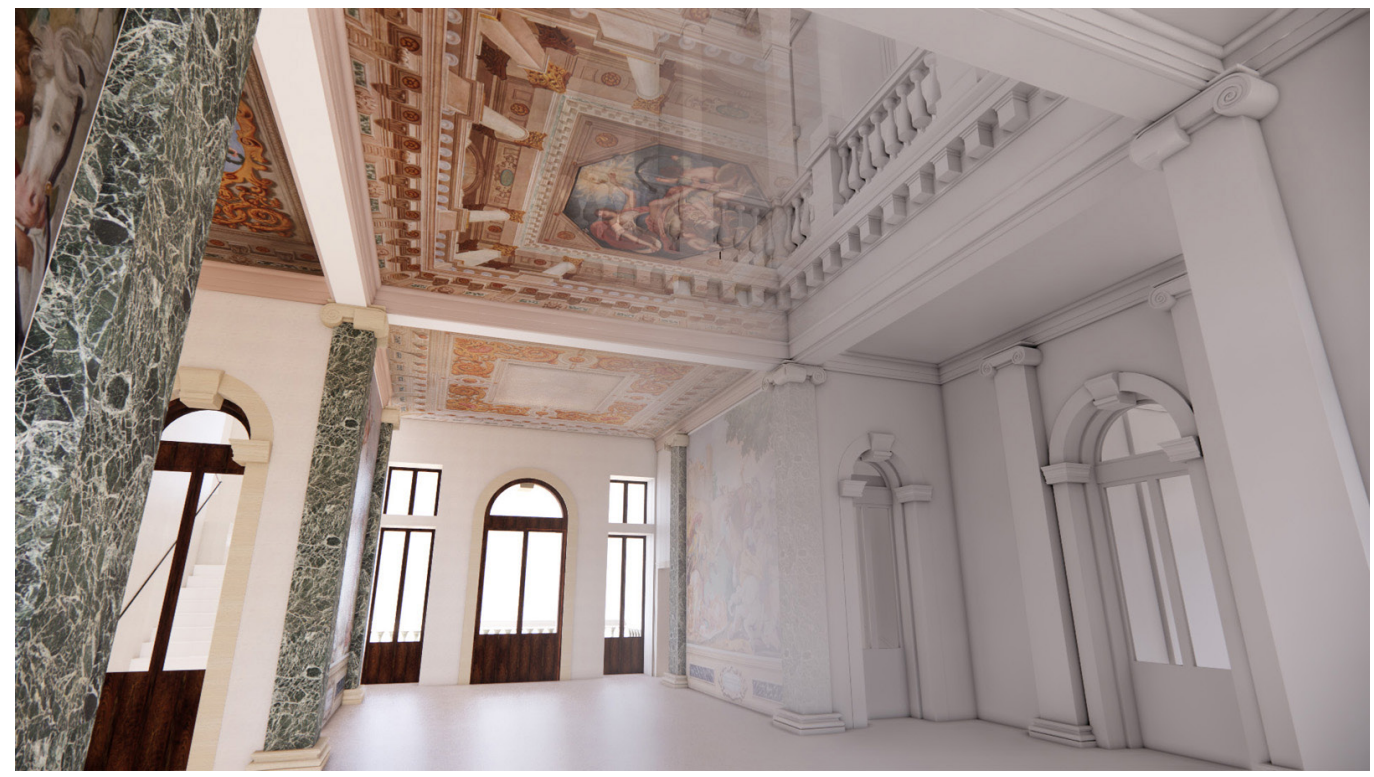

Guidati da queste finalità e sempre a partire dal modello BIM di Villa Selvatico, si sono prodotti due contenuti multimediali utilizzando un software di real-time rendering.

II primo video si concentra sulle prospettive architettoniche dipinte, con l'obiettivo di indagare la connessione che esse instaurano con l'osservatore e di elevarla a un livello di fruizione superiore, permettendo all'utente di entrare con i propri occhi nell'ambiente dipinto, a compimento così del volere del quadraturista. Attraverso la sovrapposizione di una duplice Realtà Virtuale, il visitatore può accedere alla villa nella sua dimensione più fedele al mondo fisico e allo stesso tempo è portato in contatto con l'ambientazione architettonica pensata dal pittore, assistendo con stupore a qualcosa che normalmente è intangibile e vivendo un'esperienza 'aumentata' rispetto perfino a una visita on-site (fig. 8).

In favore di un'esperienza di apprendimento naturale e di una diffusione capillare si è deciso di applicare una modalità di rappresentazione mista tra Realtà Virtuale e Aumentata,

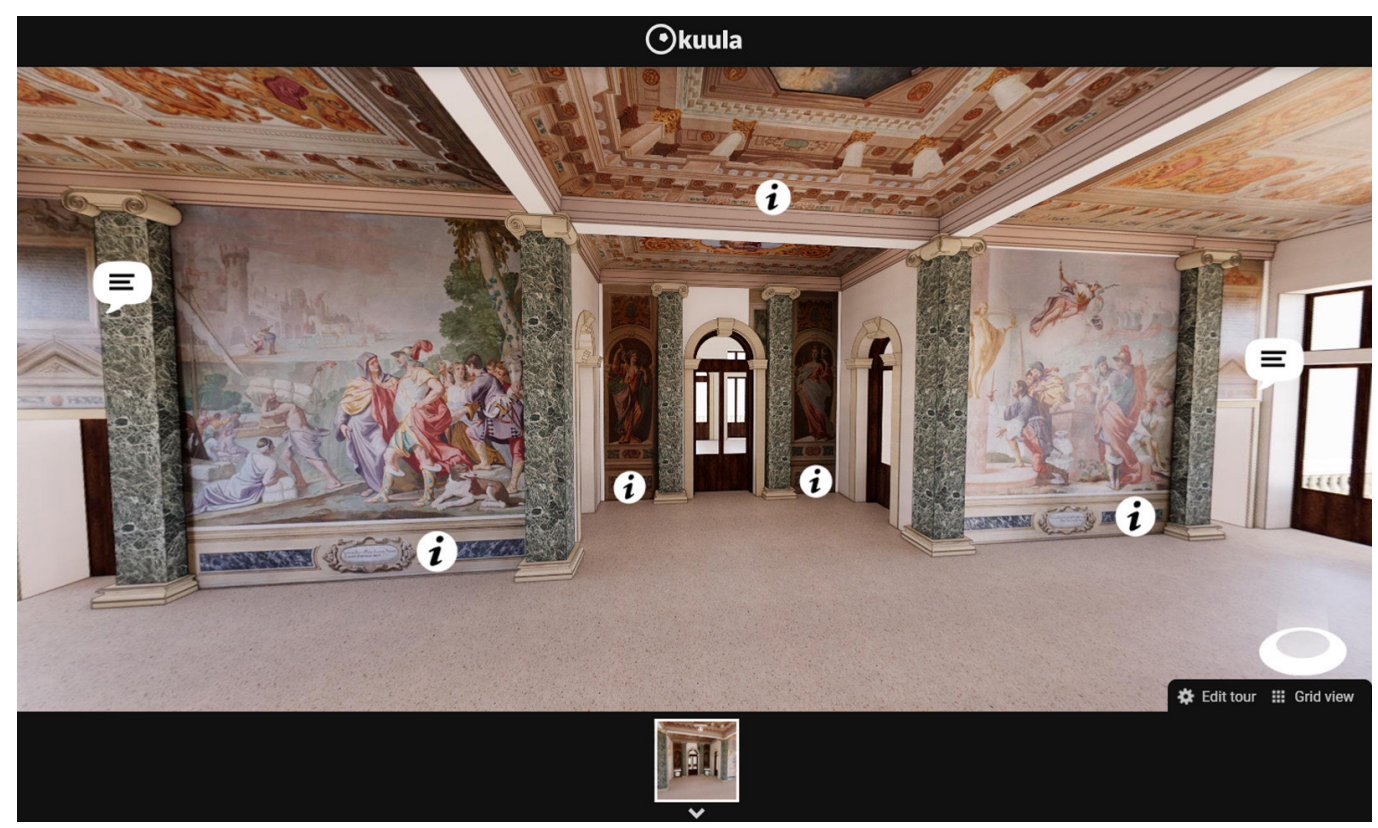


scegliendo consapevolmente di non implementare dispositivi immersivi, ma solo l'utilizzo di un semplice smartphone. Sempre in questi termini, è stato realizzato anche un tour virtuale attraverso gli interni della Villa, progettato per permettere al visitatore di interagire con i cicli pittorici. All'interno di un cammino virtuale prestabilito a partire da immagini stereoscopiche, semplici gesti per poter visualizzare foto, ascoltare contenuti audio, leggere un testo o visionare un documento storico (fig. 9).

Con quanto prodotto, si configura una grande opportunità per divulgare una conoscenza multidisciplinare e per conservarla all'interno di una memoria virtuale, dimostrando di essere uno strumento multimediale modulare in grado di adattarsi alle esigenze dell'utente, il quale è libero di muoversi all'interno della struttura di informazioni del tour, scegliendo un livello di fruizione compatibile con il proprio interesse personale [Giordano et al. 20 I6, pp. 353-358].

II mondo dell'architettura storica, seguendo le tendenze che caratterizzano il settore museale in generale, ha bisogno di avvicinarsi a nuovi strumenti di comunicazione in grado di aumentare il coinvolgimento e il proprio livello di fruizione, implementando tecnologie attualmente disponibili e validando un metodo applicabile anche su larga scala [Carci et al. 2019, pp. 274-286] [I].

\section{Note}

[I] Rachele A. Bernardello ha scritto il capitolo Processi Scan-to-BIM per la restituzione informativa dello spazio, Andrea Momolo ha scritto i capitoli: La restituzione prospettica di un'architettura dipinta e Tecniche e linguaggi per comunicare il bene culturale.

\section{Riferimenti bibliografici}

Bertocci S., Bercigli M. (2020). Le quadrature di Palazzo Pavesi a Pontremoli : il contributo del rilievo digitale per la comprensione del processo creativo delle decorazioni di una dimora barocca. In S. Bertocci, F. Farneti (a cura di). L'architettura dipinta: storia, conservazione e rappresentazione digitale. Firenze: didapress, pp. I38- I 40.

Brumana R. et al. (20I3). From survey to HBIM for documentation, dissemination and management of built heritage: The case study of St. Maria in Scaria d'Intelvi. Proceedings of the DigitalHeritage 2013 - Federating the 19th Int'I VSMM, I0th Eurographics GCH, and 2nd UNESCO Memory of the World Conferences, Plus Special Sessions fromCAA, In Arqueologica 2.0, I, pp. 497-504.

Brunelli B., Callegari A. (193I). Ville del Brenta e degli Euganei. Milano:Treves.

Carci G., Caforio A., Gamper C. (2019). Digital technologies and museums: augmented reality, learning and audience development. In Form@re: Open Journal per la Formazione in Rete, I9(I), pp. 274-286.

Champion E. M. (2019).Virtual reality adds to tourism through touch, smell and real people's experiences. In The conversation UK $<$ https://theconversation.com/virtual-reality-adds-to-tourism-through-touch-smell-and-real-peoples-experiences- 0 | $528>$ (consultato il 14 maggio 202I).

Colombo E., Marasco A. (2020). Esperienze e modelli di servizio per l'innovazione digitale nel turismo culturale. In A. Morvillo, E. Becheri (a cura di). Dalla crisi alle opportunità per il futuro del turismo in Italia. Napoli: Rogiosi editore, pp. 95- I02.

De Rosa A. et al. (2020). L'Architettura dipinta della Scoletta del Carmine a Padova. In S. Bertocci, F. Farneti, D. Lumare (a cura di). L'architettura dipinta: storia, conservazione e rappresentazione digitale. Firenze: didapress, pp. 219-227.

Fantelli P. L. (1989). Ville venete a Battaglia Terme. In P. G.Zanetti (a cura di). Battaglia Terme, originalità e passato di un paese del Padovano. Battaglia Terme: La Galiverna Editrice, pp. 95- 100.

Fasolo O. (1992). Illusioni prospettiche unitarie d'architettura (Architettura prospettica nella Wandmalerei e Deckenmalerei ). In XY, dimensioni del disegno, 16, 1992, p. 83

Garagnani S. (2014). Modellazione parametrica e semantica BIM. Ricostruzione visuale della prospettiva in affresco nella Sala Urbana del Palazzo Comunale a Bologna. In G.M. Valenti (a cura di). Prospettive architettoniche l: conservazione digitale, divulgazione e studio. Roma: Sapienza Università Editrice, pp. 357-369.

Giordano A. et al. (20/8). Le opportunità fornite dai nuovi strumenti digitali (The opportunities of the new digital tools). Narrare le città e i suoi cambiamenti attraverso la rappresentazione BIM-CAD. Paesaggio Urbano, 4. Rimini: Maggioli, pp. 5 I -73.

Giordano A., Nichele C. (2016). L'Architectura Picta e la realizzazione della chiesa ideale a pianta centrale: il ruolo della rappresentazione per la conoscenza, l'elaborazione e la comunicazione tra ricerca e fruizione turistico-culturale. In S. Bertocci, M. Bini (a cura di). Le Ragioni del Disegno. Pensiero, Forma e Modello nella Gestione della Complessità. Atti del $38^{\circ}$ Convegno Internazionale dei Docenti della Rappresentazione, Firenze I5- 17 settembre 20 16, pp. 353-358. Roma: Gangemi editore.

King L., Stark J. F., Cooke P. (20 I6). Experiencing the Digital World:The Cultural Value of Digital Engagement with Heritage. In Heritage and Society, $9(\mathrm{I}), \mathrm{pp} .76-101$. 
Logothetis S., Delinasiou A. Stylianidis E. (2015). Building information modelling for cultural heritage. In ISPRS Annals of the Photogrammetry, Remote Sensing and Spatial Information Sciences, 2(5W3), pp. 177-183.

Marasco A., Balbi B. (2019). Designing Accessible Experiences for HeritageVisitors Through Virtual Reality. In e-Review ofTourism Research (eRTR), I7(3), pp. 426-443.

Migliari R. (20 I4). Le prospettive architettoniche: un ponte tra arte e scienza. In G.M.Valenti (a cura di). Prospettive architettoniche I: conservazione digitale, divulgazione e studio. Roma: Sapienza Università Editrice, pp. I-4.

Sgrosso A. (1979). Note di fotogrammetria applicate all'architettura. Napoli: Lithorapid.

Succar B. (2019). 2 I lin Model Uses Table: <https://doi.org/I 0.528I/ZENODO.3563403> (consultato il I4 maggio 202 I).

Autori

Rachele Angela Bernardello, Università di Padova, racheleangela.bernardello@phd.unipd.it Andrea Momolo, Università di Padova, andrea.momolo@unipd.it

Per citare questo capitolo: Bernardello Rachele Angela, Momolo Andrea (2021). Connessioni figurative e informative tra lo spazio costruito e lo spazio pittorico/Figurative and informative relations between the built space and the pictorial space. In Arena A., Arena M., Mediati D., Raffa P. (a cura di). Connettere. Un disegno per annodare e tessere. Linguaggi Distanze Tecnologie. Atti del $42^{\circ}$ Convegno Internazionale dei Docenti delle Discipline della Rappresentazione/Connecting. Drawing for weaving relationship. Languages Distances Technologies. Proceedings of the $42^{\text {th }}$ International Conference of Representation Disciplines Teachers. Milano: FrancoAngeli, 225-244. 


\title{
Figurative and Informative Relations between the Built Space and the Pictorial Space
}

\author{
Rachele Angela Bernardello \\ Andrea Momolo
}

Abstract

The physical-figurative relation between the built space and the architectural pictorial space is a representation theme that has always been explored to catch the most complex technical and theoretical aspects of the quadraturism masters. An innovative approach to these scenarios is allowed by the Building Information Modeling methods. In fact, the possibility of linking different figurative and information structures in a unique digital platform, making explicit their physical relationships through a hierarchical data structure and increasing the immersive experience with perspective restitution techniques and virtual tools, guarantees to improve the experiences that always coexist in the cultural heritage: the user's one and the scholars' one.

This research flow, implemented at Villa Selvatico in Battaglia Terme, made it possible to represent the built and painted realities, which can be interrogated both to plan conservation and management activities, and to enable an enhancement touristic path. In particular, the Scan-to-BIM process guarantees to reconstruct the link between architecture and pictorial space, relating the different semantic elements in spatial and functional terms.

Finally, the information structure adopted has shown that it can dialogue with engaging visualization techniques such as VR, exploring new languages to communicate knowledge, particularly effective in this period in which distances from the cultural world have become physical.

Keywords

BIM, perspective restitution, virtual reality, pictorial space, immersive space.

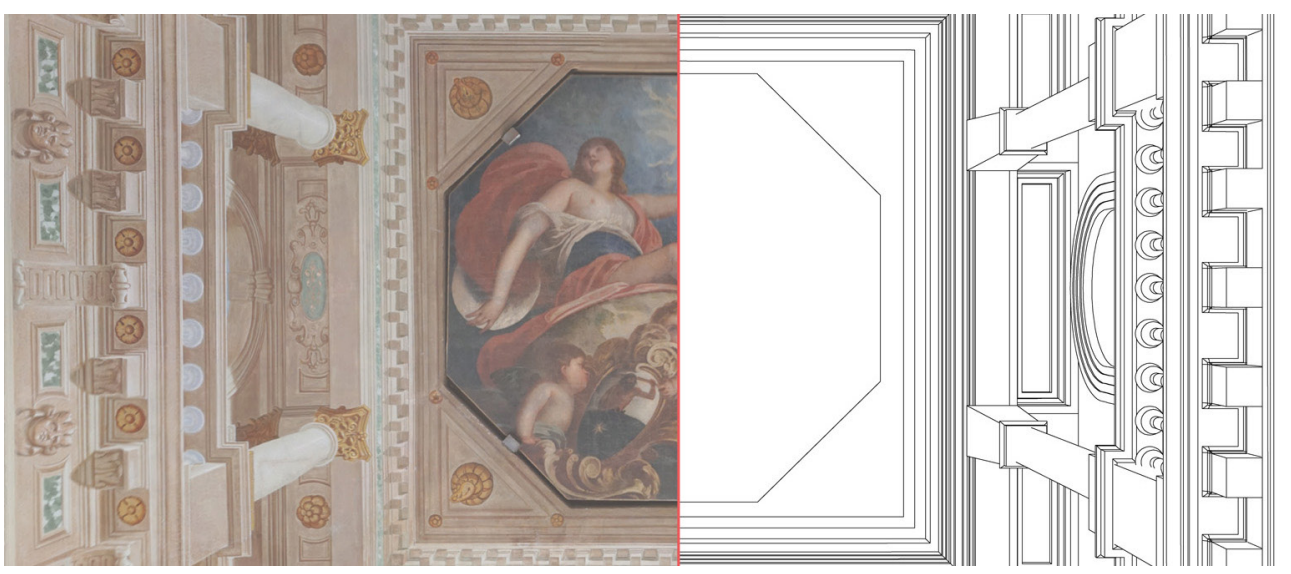




\section{Scan-to-BIM processes for space informative representation}

The methods for the conservation and enhancement of the historical heritage, which take advantage of digitization and data processing processes, allow the definition and experimentation of cognitive and emotional paths for the user and at the same time technical-scientific for the professionals in the sector too.

A particular declination of this cultural process concerns interior spaces embellished with frescoes of Baroque quadraturism which, by their nature, enhance a deep link between what is the physical, real and tangible architectural space, and the planar pictorial space, governable and only observable. The generative nature characterized by the dynamic intertwining of art and science of this pictorial genre necessarily develops towards an organized and multidisciplinary approach [Migliari 2014 , pp. I-4]. For this reason, in recent decades, the quadrature and the historic buildings that house them have become stimulating laboratories for several professionals: scholars of the science of representation, architects, engineers, as well as art and architecture historians.

Furthermore, technological development and procedural experimentation increasingly demonstrate how much there is the possibility of coordinating different purposes and intentions through the tools of digital representation, guaranteeing through the organization of collaborative platforms, the coordination, and continuation of parallel activities on the same artifact.

This plurality within the same digital model is guaranteed by the implementation of Building Information Modeling as an operational process, it turns out to be the ideal information environment in which to express different uses of the model, integrate the architectural and pictorial dimension, design virtual experiences for tourist-museum knowledge.

The experience described on Villa Selvatico in Battaglia Terme states this virtuous workflow, according to the phases: the digital survey of the artifact, the processing of data and the production of a BIM model, the perspective restitution of the pictorial framework, the planning of a multimedia enhancement path.

The interesting condition of Villa Selvatico from a historic-architectural and management viewpoint is a fundamental example in the BIM-based methodology implementation aimed at defining scenarios for the management and enhancement of Heritage based on the reconnection in a virtual environment of the painted space and the built space. It is, indeed, a seventeenth-century Venetian Villa that benefits from a prestigious landscape position, standing at the foot of the Euganean Hills (fig. I).

Fig. I. Perspective view of Villa Selvatico in an engraving dated 1823 (Biblioteca del Museo Civico di Padova).

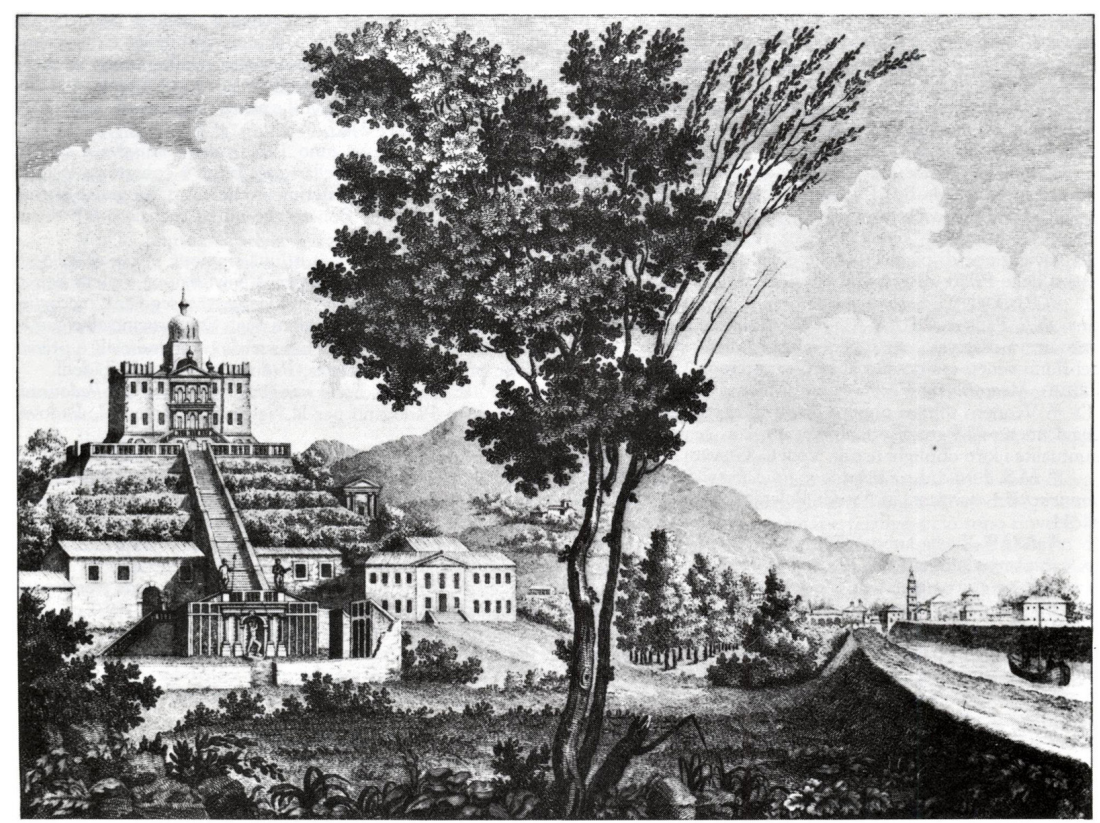


Provided with considerable artistic value connected to the pictorial cycles that embellish the interior rooms, including interesting examples of Baroque Quadraturism, the Villa is an exceptional place where architectural space and pictorial space are deeply related (fig. 2).

The intent to improve the user and professional experience in different digital environments by exploiting more tools, but referring to the same information object, allows guaranteeing a close relationship between the digital clone of the architectural elements with the frescoes and their digital elaborations. Starting from an initial definition of the uses of the model and the purposes of the information restitution process, identifiable in the survey and representation series and in connection and extension [Succar 2020], it was possible to proceed with the BIM modeling, based on a 2D digital survey carried out from a 2005 restoration project and integrating it with a photogrammetric survey of the main frescoed interior spaces. The use of different acquisition methodologies depending on the needs to be met during and at the end of the entire process is determined by a matrix of values that responds to multidisciplinary factors including the geometric-architectural conformation and the final output. The BIM model, capable of being both a container of technical information put at professionals' disposal and a powerful vehicle for disseminating the historic building itself and its related figurative apparatuses, offers a dual utility that always emerges in the context of fine historical architecture [Logothetis et al 20 I5, pp. I77- I83].

We wanted to demonstrate among the various benefits that the use of BIM multiplies about the existing valuable heritage, which could not only manage and document the historic building but also communicate and disseminate the cultural heritage, interacting with new technologies and experimenting innovative representation methods [De Rosa et al. 2020, pp. 219-227, Brumana et al. 2013, pp. 497-504]carried out in collaboration between Polimi (Italy).

The parametric modeling of the space of real architecture was placed side by side with that of the pictorial space represented in the trompe-l'oeil frescoes. The two realities are also combined by generative restitution processes: just as the model of the Villa is based on the Scan-To-BIM method, therefore starting from the drawings of a digital survey, the pictorial environment is also based on a restitution process. geometric able to bring the architectures represented in perspective into a three-dimensional space.

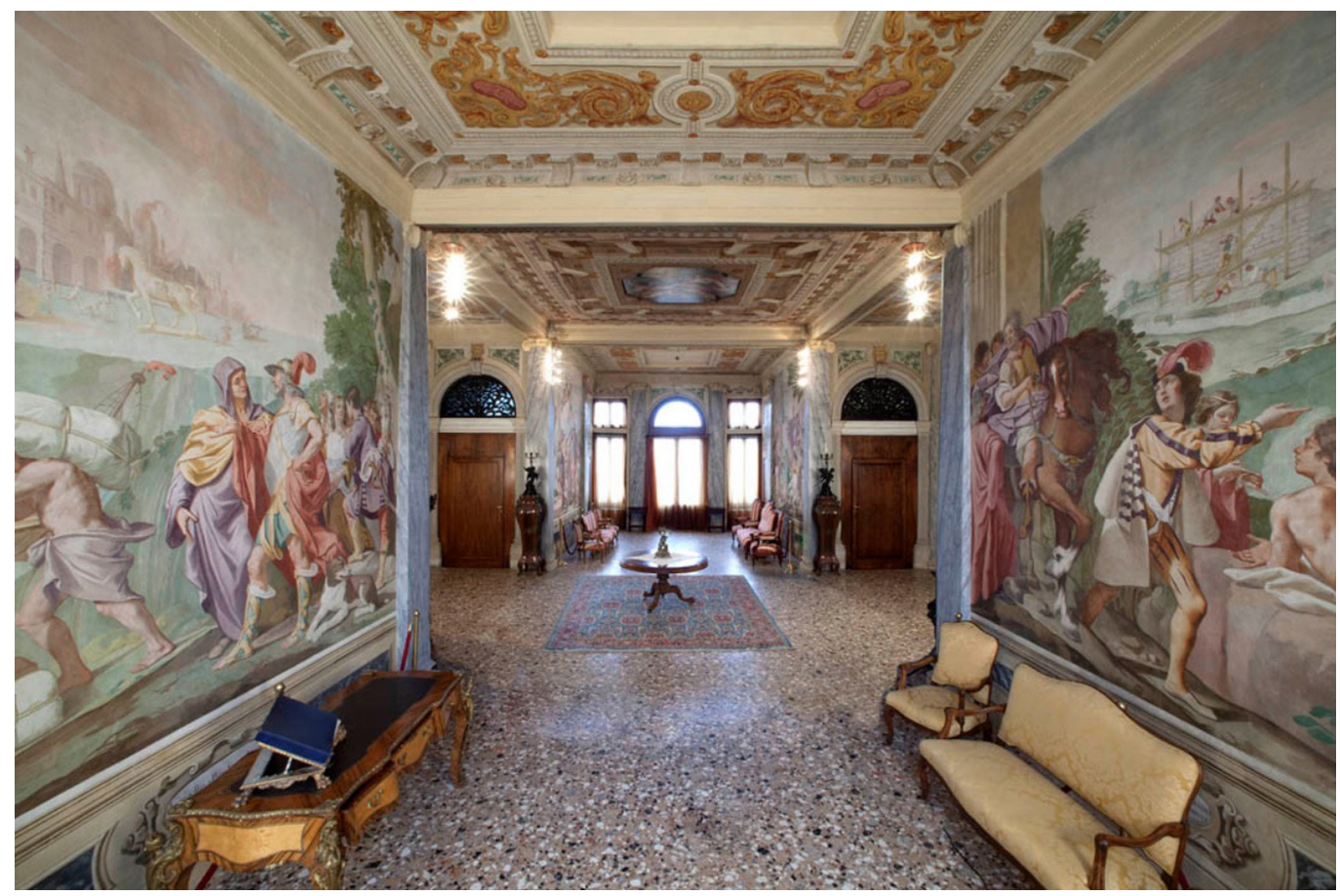


The possibility of associating in the BIM model the own information carried by the survey outputs, such as the point cloud of the real space and the orthophotos of the painted space, with the informative digital objects defines the crucial node of this research activity which is expressed in its completeness in the last phase of this process [Giordano et al. 20 I8], namely the sharing of an integrated digital reconstruction that allows you to immerse yourself not only in the reality of the historic Villa but also in the virtual spaces designed with great skill and technical knowledge by artists who lived more than 400 years ago.

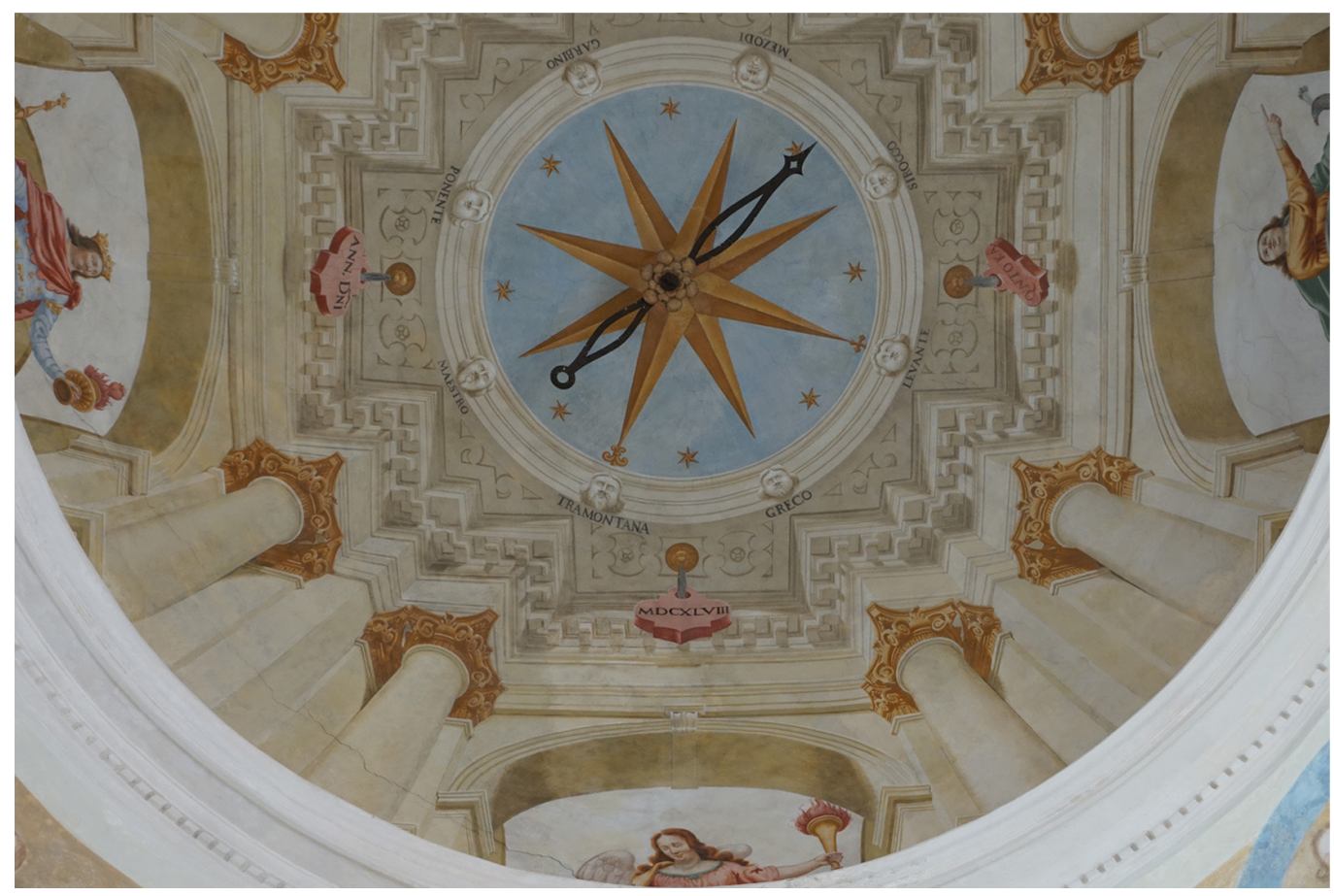

\section{The perspective restitution of a painted architecture}

$$
\begin{array}{r}
\text { "Any architectural perspective, on canvas or a wall, } \\
\text { is a perspective illusion. He pretends an architecture that doesn't exist" } \\
\text { [Fasolo I992, p. 83] }
\end{array}
$$

Thus, begins an essay from 1992 in which Fasolo suggests a classification of architectural perspectives based on the precise relationship they establish with real architecture.

He defines as first-degree perspectives those in which there is no close link between real space and represented space, distinguishing them from second-degree ones which, on the contrary, are studied ad hoc to create an illusory continuation between imaginary architecture and real architecture.

The pictorial apparatus has assumed a central role in the reconstruction and digital representation of Villa Selvatico.

In 1658, the complex had come to house an art gallery, with paintings and works by some of the most influential artists of the time [Fantelli 1989, pp. 95- 100]. Unfortunately, today this precious collection has been lost except for the cycles of frescoes which, recently restored, completely adorn the cruciform hall on the first floor and the dome on the upper floor. The artistic authorship of these rooms belongs to two painters from Reggio Emilia, who between 1647 and 1650 worked jointly dividing the subjects according to their architectural or figurative typology. Lorenzo Bedogni had worked mainly as an architectural painter painting the colonnade inside the dome (fig. 3 ) then a series of perspective quadrature downstairs 
Fig. 4: First floor plan with overturned orthophotos of the frescoed walls and ceilings.

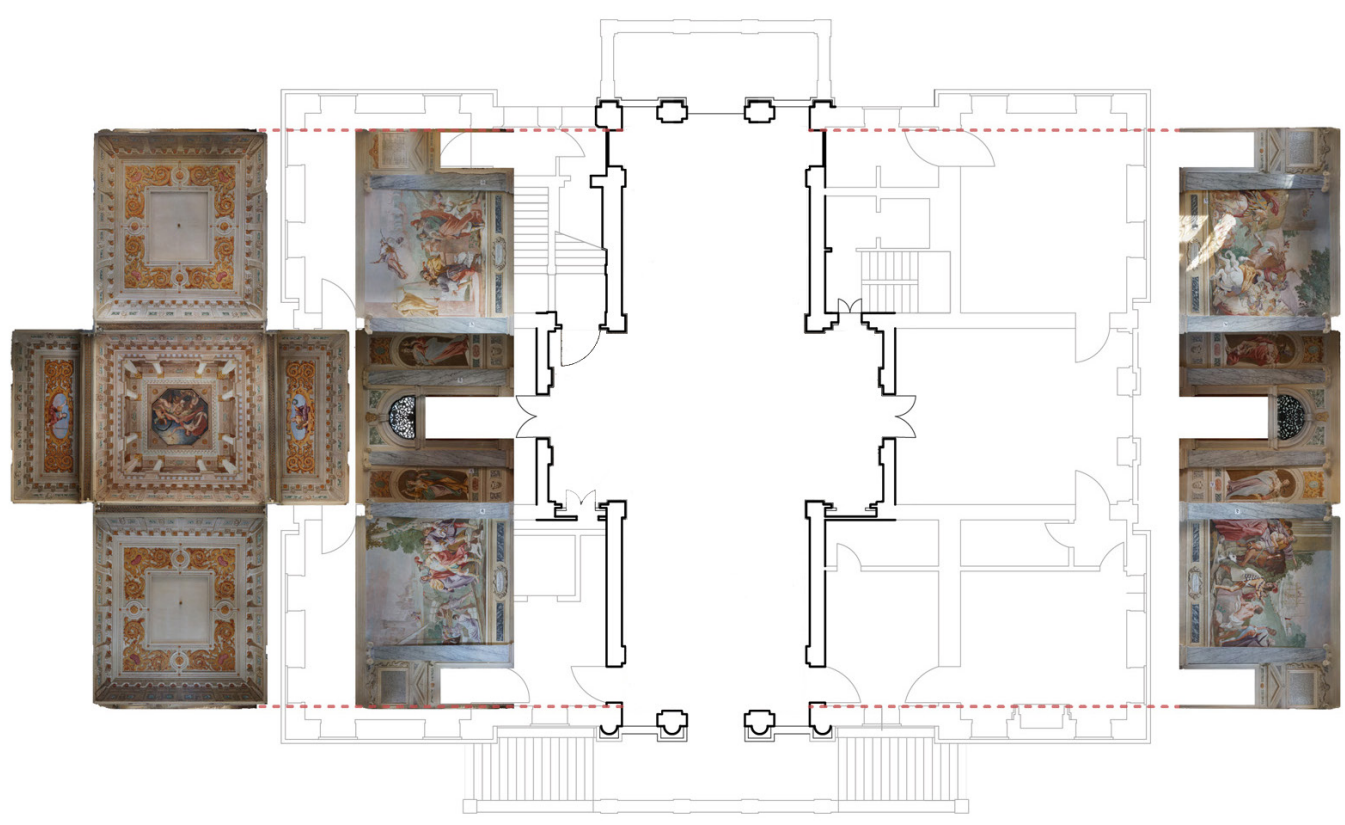

(fig. 3). Luca Ferrari had depicted on the walls of the long arms of the room four episodes of the myth of Antenore (fig. 4) [Brunelli et al. I93I, Fantelli I989, pp. 95- I00]. These, while representing fascinating examples of Baroque painting, but not having any substantial architectural references within them, have not been the subject of perspective restitution, but have simply been mapped and classified within the information apparatus of the BIM model. More attention was instead placed on the perspective quadrature in which the existence of a close relationship between painting and architecture is evident, in which painting and architecture dialogue clearly and directly. Therefore, this ideal connection was investigated and subsequently represented by using the perspective restitution techniques. In this way, by making tradition relate with innovative technological tools, it was possible to recreate and share the architectural space painted by Lorenzo Bedogni, thus giving a form, albeit virtual, to the strong link that he had wanted to establish between pictorial representation and architectural spatiality (fig. 5).

The fresco on the central ceiling on the first floor is the most complete both for the complexity of the architectural scene represented and for the illusory efficacy. The restitution operations were performed using the orthophoto processed by the photogrammetric survey. The scene painted doubly symmetrical, does not host any human figure, and is marked by a series of elements that simulate the breakthrough of the upper floor, composing a square-plan loggia marked by Corinthian columns and pillars. Above the projecting cornice in the foreground, the hypothetical floor of the loggia is set, divided by four pillars at the corners and two columns on each side, all Corinthian order.These rest on massive bases which in turn articulate the balustrade parapet. Finally, the architectural perspective ends with a decorated ceiling dug in the center by an octagon that houses the Padovanino altarpiece depicting The glory of the house Selvatico.

The main point was found by extending all the perspective lines orthogonal to the painting, which converge exactly in the central point of the painting, confirming that it is a monocentric perspective. Once the identification of the perspective reference was completed, it was possible to start the restitution of the architectural apparatus [Sgrosso 1979], and to combine the ideal space of the frescoes with the digital reconstruction of the real space, importing the 3D geometric model file into the BIM environment (fig. 6). Once correctly positioned above the ceiling of the first floor, the coexistence of the two models made it possible to investigate the characteristics of the painted space and to make some considerations regarding the architectural and perspective layout imagined by the painter. 
Fig. 5. Orthophoto of the central ceiling compared with the virtually

reconstructed pictoria space.

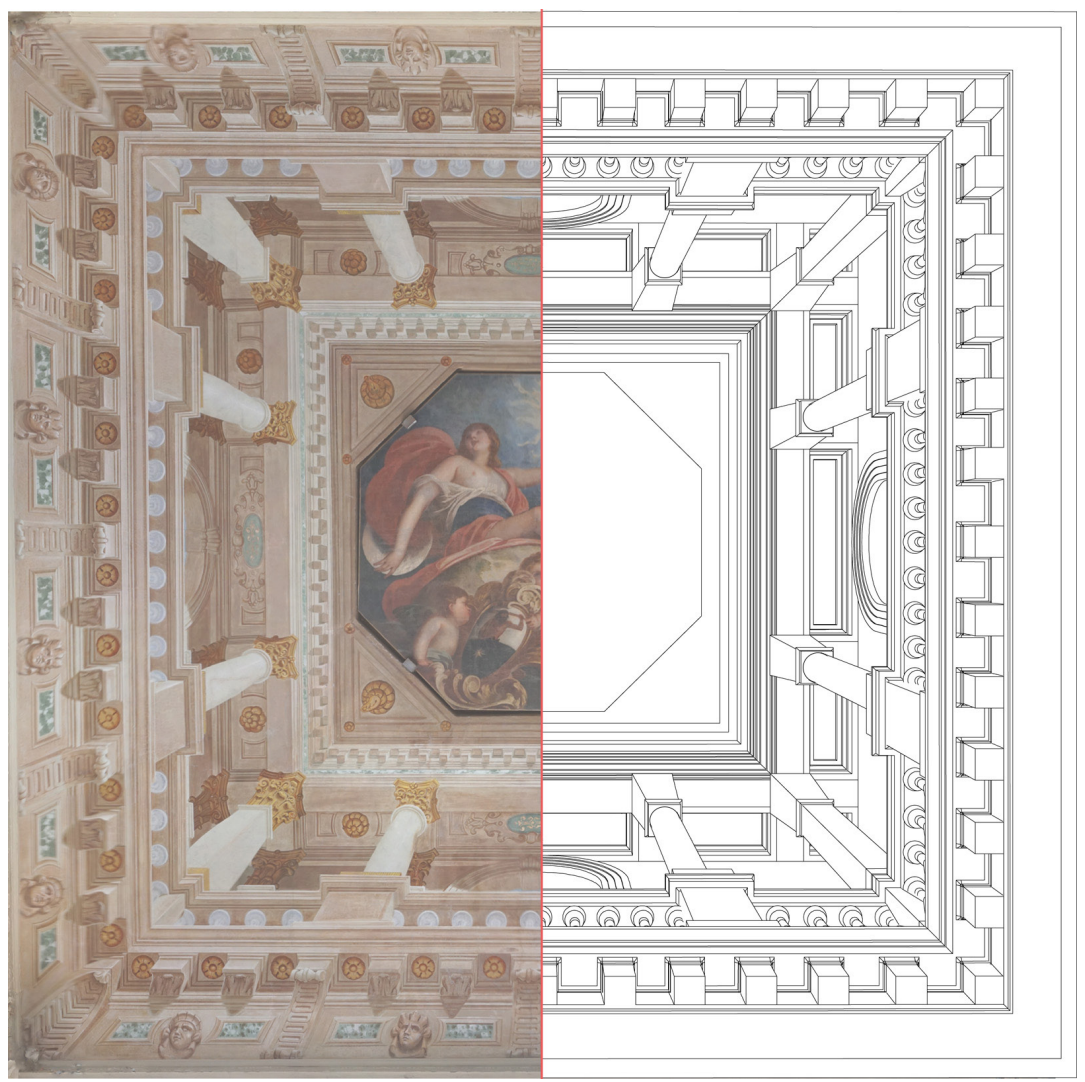

Fig. 6. Perspective

restitution of plan and

section of the painted space.

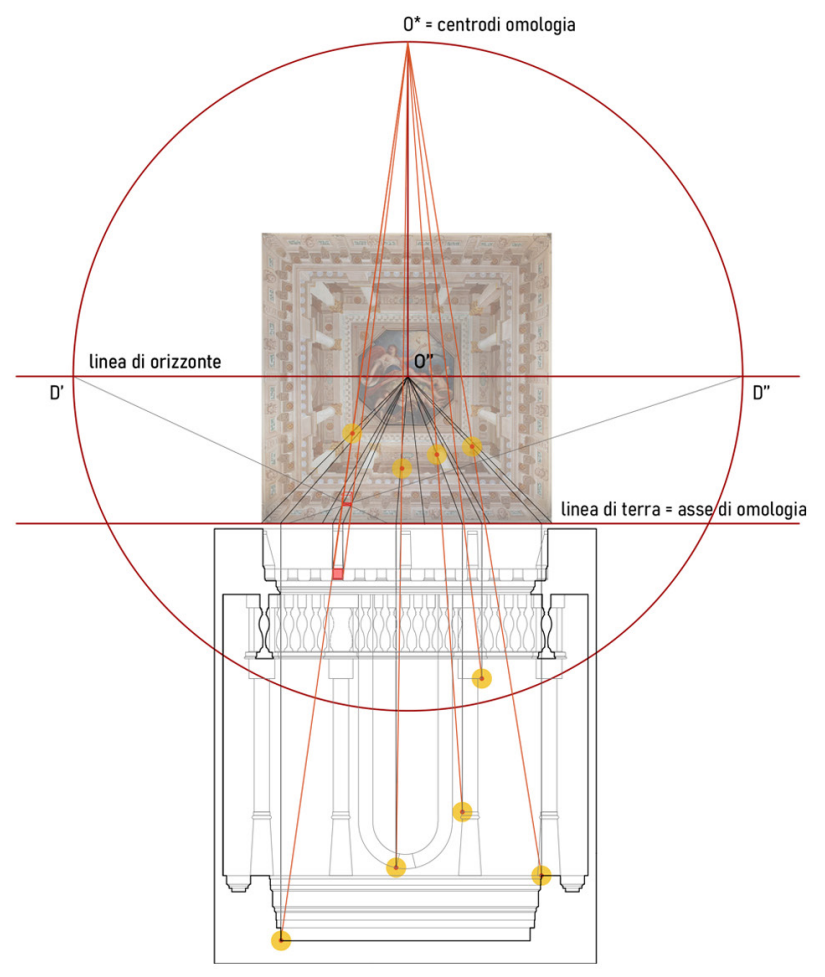


Fig. 7. Longitudinal section of the $3 d$ pictorial environment properly model of the Villa.
As can be seen from the section view (fig. 7), the main distance determined with the perspective restitution is $5.90 \mathrm{~m}$ which is far greater than the real distance between the painting and the observer's eye (about 3, $20 \mathrm{~m}$ ). This implies that the ideal observer would be positioned outside the space of the frescoed room and precisely I m below the floor. By comparing the elements of the painted space with the real ones, significant inconsistencies and notable oversizing were noted, which contributed to 'unveil' some perspective aberrations, which however are not to be considered as errors, but as expedients studied by the painter to fix the reduced height of the compartments about the dimensions of the virtual construct [Bertocci et al. 2020, pp. I38- | 40]. In this way, the perception of the painted space is modified ad hoc to be appreciated from a closer point of view than the theoretical one but entailing the creation of an ideal space with dimensions that clash with the human scale.

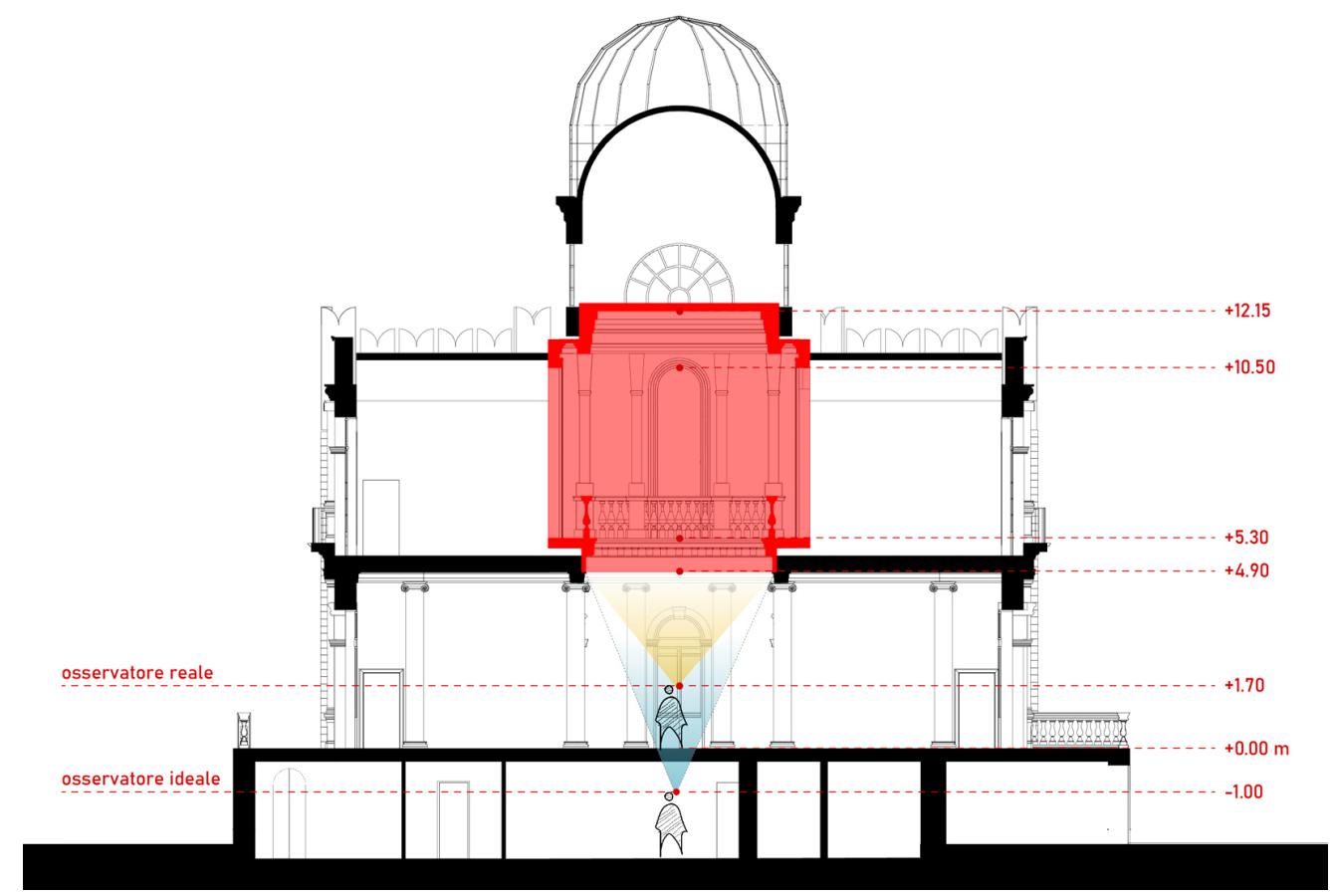

Techniques and languages to communicate the Cultural Heritage

In the last phase of research, particular attention was paid to the new technologies introduced in the field of representation and to the relationships that could be established between them and the BIM model. knowing the promising capacity of BIM as a process capable of expanding the potential of the Drawing language towards a digital environment [Garagnani 2014, pp. 357-369] it was decided to rely on virtual representation to translate analyses and elaborations carried out into multimedia 3D reconstructions, easily shared on online platforms.

This choice takes on a significant value in the historical moment we are experiencing, characterized by the healthcare need to keep distance, not only interpersonal but also from places of culture. In this difficult period, the role of technological innovation as a solution capable of breaking down the physical barriers that are bringing essential sectors like this to their knees is increasingly central [Colombo et al. 2020, pp. 95-102].

To attract tourists and promote cultural heritage, there is also the need to emotionally involve visitors, to adopt a user-centric perspective, considering the virtual space not only as a function of the physical one but above all as an opportunity to offer a new type of experience [Champion 2019, King et al. 2016, pp. 76- I0I, Marasco et al. 2019, pp. 426-443]. 
Fig. 8. Comparison of two views acquired from the same observation point On the left side there is the pictorial space implemented in the Villa viewed in conceptual mode; on the right, the architectural space is displayed in a realistic

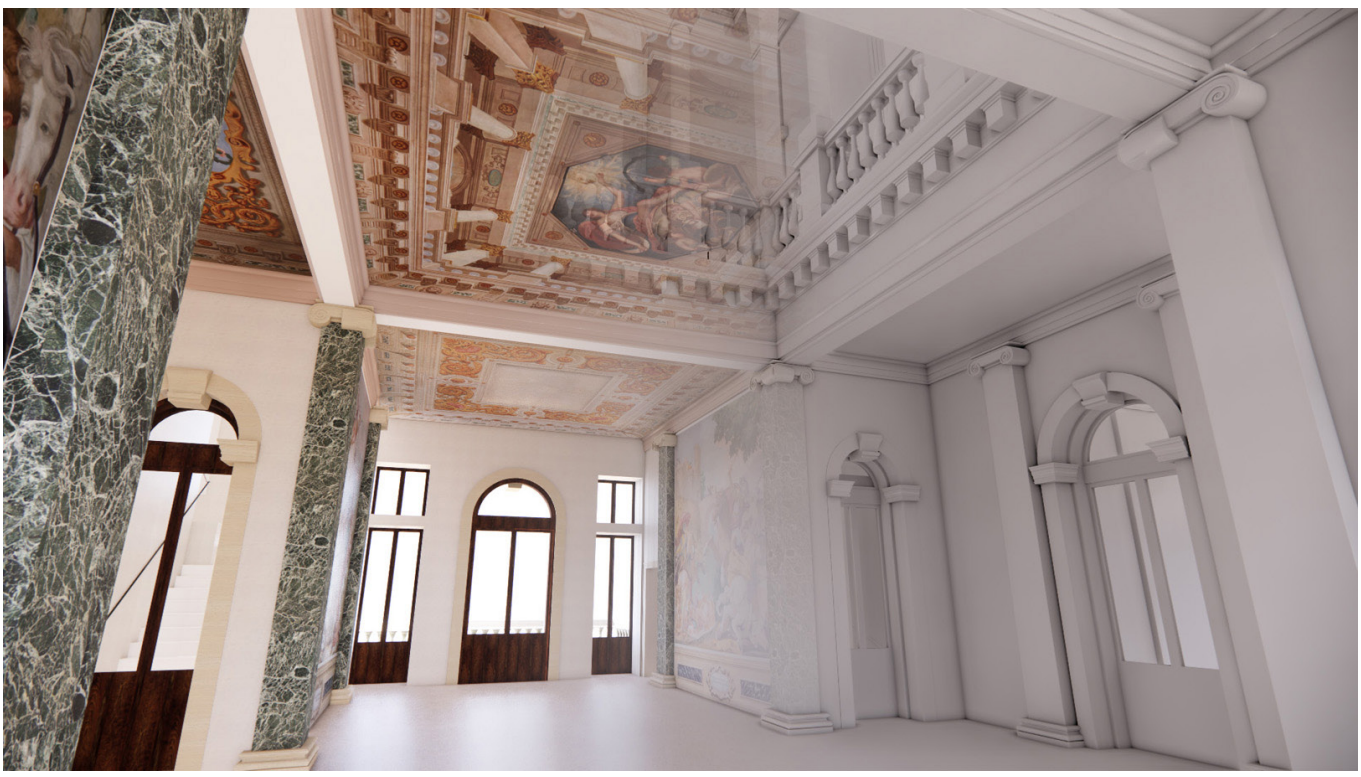

Guided by these aims and always starting from the HBIM model of Villa Selvatico, two multimedia contents were produced using real-time rendering software.

The first video focuses on the painted architectural perspectives, to investigate the connection they establish with the observer and raise it to a higher level of use, allowing the user to enter the painted environment with its own eyes, thus fulfilling the wish of the painter. Through the superimposition of a double Virtual Reality, the visitor can access the Villa in its most faithful dimension to the physical world and at the same time is brought into contact with the architectural setting conceived by the painter, witnessing with amazement something that is normally intangible and so living an 'augmented' experience compared to even an on-site visit (fig. 8).

Preferring a natural learning experience and widespread diffusion, it was decided to apply a representation mode that mixes virtual and augmented reality, consciously choosing not to implement immersive devices, using a simple smartphone. The main objective is to disseminate and share the heritage represented by the Villa and, at the same time, to ensure

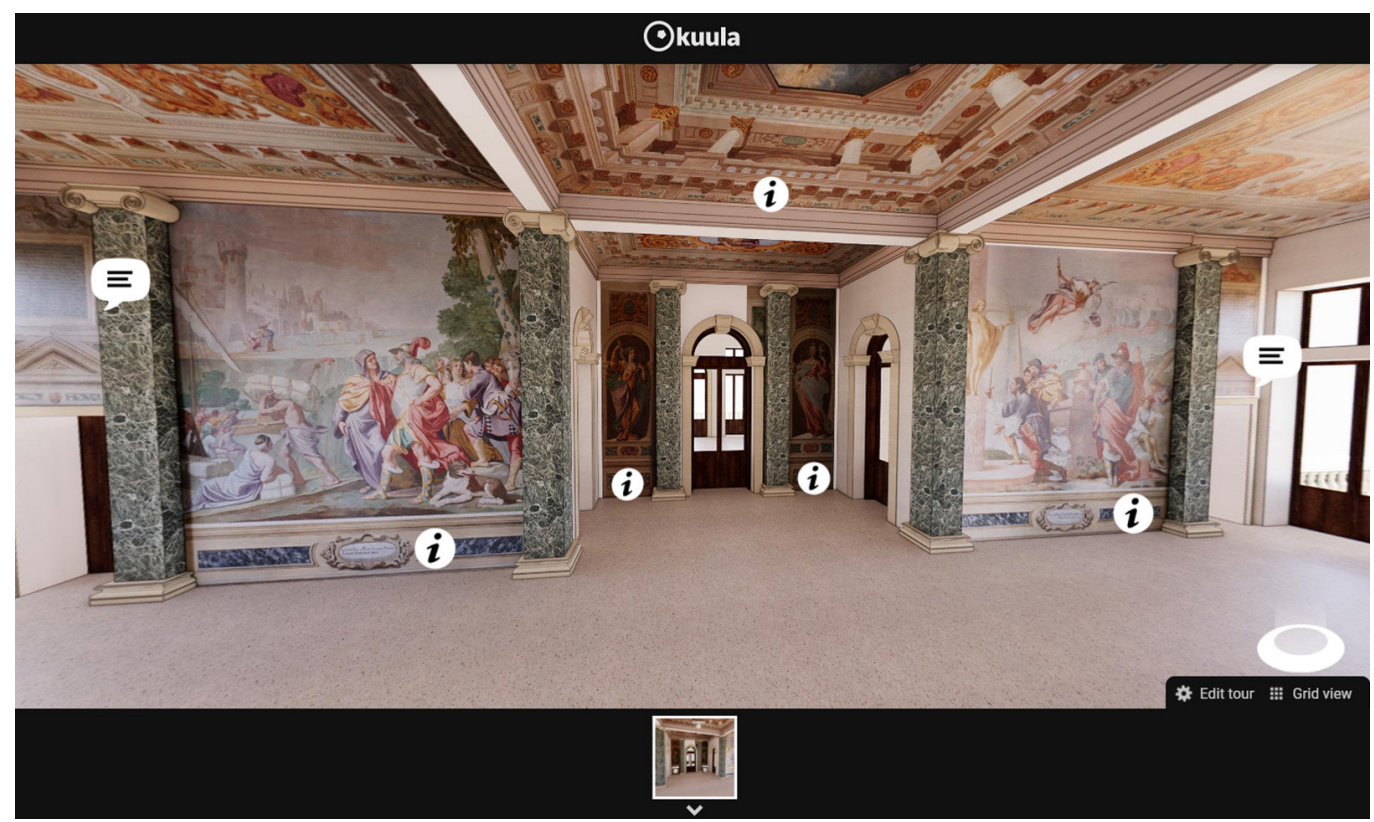


greater cultural accessibility that is not only physical but also cognitive, facing the difficulties of communicating with a heterogeneous public. Following these ideas, a virtual tour was created through the interiors of the Villa, designed to allow the visitor to interact with the pictorial cycles. Within a predetermined virtual path starting from stereoscopic images, a simple click is enough to view photos, listen to audio content, read a text, or view a historical document (fig. 9).

This represents a great opportunity to disseminate multidisciplinary knowledge and to store it within a virtual memory. Furthermore, it proves to be a modular multimedia tool able to adapt to the needs of the user, who is free to move within the information structure of the tour, choosing a level of use compatible with their interest [Giordano et al. 2016, pp. 353-358].

In conclusion, this experimentation does not want to be an end, but to offer ideas on how to exploit new technologies for the description and presentation of architectural contents. The world of historical architecture, following the trends that characterize the museum sector in general, needs to approach new communication tools capable of increasing involvement and its level of fruition and validating a method that can also be applied on a large scale [Carciet et al. 2019, pp. 274-286] [1].

\section{Notes}

[I] Rachele Bernardello is the author of the chapter Scan-to-BIM processes for space informative representation; Andrea Momolo is the author of the chapters The perspective restitution of a painted architecture and Techniques and languages to communicate the Cultural Heritage.

\section{References}

Bertocci S., Bercigli M. (2020). Le quadrature di Palazzo Pavesi a Pontremoli : il contributo del rilievo digitale per la comprensione del processo creativo delle decorazioni di una dimora barocca. In S. Bertocci, F. Farneti (a cura di). L'architettura dipinta: storia, conservazione e rappresentazione digitale. Firenze: didapress, pp. I38- I 40.

Brumana R. et al. (20I3). From survey to HBIM for documentation, dissemination and management of built heritage: The case study of St. Maria in Scaria d'Intelvi. Proceedings of the DigitalHeritage 2013 - Federating the 19th Int'I VSMM, I0th Eurographics GCH, and 2nd UNESCO Memory of the World Conferences, Plus Special Sessions fromCAA, In Arqueologica 2.0, I, pp. 497-504.

Brunelli B., Callegari A. (193I). Ville del Brenta e degli Euganei. Milano:Treves.

Carci G., Caforio A., Gamper C. (2019). Digital technologies and museums: augmented reality, learning and audience development. In Form@re: Open Journal per la Formazione in Rete, I9(I), pp. 274-286.

Champion E. M. (2019).Virtual reality adds to tourism through touch, smell and real people's experiences. In The conversation UK <https://theconversation.com/virtual-reality-adds-to-tourism-through-touch-smell-and-real-peoples-experiences- I 0 | 528> (accessed 2021, May |4).

Colombo E., Marasco A. (2020). Esperienze e modelli di servizio per l'innovazione digitale nel turismo culturale. In A. Morvillo, E. Becheri (a cura di). Dalla crisi alle opportunità per il futuro del turismo in Italia. Napoli: Rogiosi editore, pp. 95- 102.

De Rosa A. et al. (2020). L'Architettura dipinta della Scoletta del Carmine a Padova. In S. Bertocci, F. Farneti, D. Lumare (a cura di). L'architettura dipinta: storia, conservazione e rappresentazione digitale. Firenze: didapress, pp. 219-227.

Fantelli P. L. (1989). Ville venete a Battaglia Terme. In P. G.Zanetti (a cura di). Battaglia Terme, originalità e passato di un paese del Padovano. Battaglia Terme: La Galiverna Editrice, pp. 95- 100.

Fasolo O. (1992). Illusioni prospettiche unitarie d'architettura (Architettura prospettica nella Wandmalerei e Deckenmalerei ). In XY, dimensioni del disegno, 16, 1992, p. 83.

Garagnani S. (2014). Modellazione parametrica e semantica BIM. Ricostruzione visuale della prospettiva in affresco nella Sala Urbana del Palazzo Comunale a Bologna. In G.M. Valenti (a cura di). Prospettive architettoniche l: conservazione digitale, divulgazione e studio. Roma: Sapienza Università Editrice, pp. 357-369.

Giordano A. et al. (20।8). Le opportunità fornite dai nuovi strumenti digitali (The opportunities of the new digital tools). Narrare le città e i suoi cambiamenti attraverso la rappresentazione BIM-CAD. Paesaggio Urbano, 4. Rimini: Maggioli, pp. 5 I -73.

Giordano A. Nichele C. (2016). L'Architectura Picta e la realizzazione della chiesa ideale a pianta centrale: il ruolo della rappresentazione per la conoscenza, l'elaborazione e la comunicazione tra ricerca e fruizione turistico-culturale. In S. Bertocci, M. Bini (a cura di). Le Ragioni del Disegno. Pensiero, Forma e Modello nella Gestione della Complessità. Atti del $38^{\circ}$ Convegno Internazionale dei Docenti della Rappresentazione, Firenze I5- 17 settembre 20 I6, pp. 353-358. Roma: Gangemi editore.

King L., Stark J. F., Cooke P. (2016). Experiencing the Digital World:The Cultural Value of Digital Engagement with Heritage. In Heritage and Society, $9(\mathrm{I}), \mathrm{pp} .76-101$. 
Logothetis S., Delinasiou A. Stylianidis E. (2015). Building information modelling for cultural heritage. In ISPRS Annals of the Photogrammetry, Remote Sensing and Spatial Information Sciences, 2(5W3), pp. 177-183.

Marasco A., Balbi B. (2019). Designing Accessible Experiences for HeritageVisitors Through Virtual Reality. In e-Review ofTourism Research (eRTR), I7(3), pp. 426-443.

Migliari R. (20|4). Le prospettive architettoniche: un ponte tra arte e scienza. In G.M. Valenti (a cura di). Prospettive architettoniche l: conservazione digitale, divulgazione e studio. Roma: Sapienza Università Editrice, pp. I-4.

Sgrosso A. (1979). Note di fotogrammetria applicate all'architettura. Napoli: Lithorapid.

Succar B. (20 I9). 2 I l in Model Uses Table. <https://doi.org/ I0.528 I/ZENODO.3563403> (accessed 202I, May I4).

Authors

Rachele Angela Bernardello, Università di Padova, racheleangela.bernardello@phd.unipd.it

Andrea Momolo, Università di Padova, andrea.momolo@unipd.it

To cite this chapter. Bernardello Rachele Angela, Momolo Andrea (202I). Connessioni figurative e informative tra lo spazio costruito e lo spazio pittorico/Figurative and informative relations between the built space and the pictorial space. In In Arena A., Arena M., Mediati D., Raffa P. (a cura di). Connettere. Un disegno per annodare e tessere. Linguaggi Distanze Tecnologie. Atti del $42^{\circ}$ Convegno Internazionale dei Docenti delle Discipline dello Rappresentazione/Connecting. Drawing for weaving relationship. Languages Distances Technologies. Proceedings of the $42^{\text {th }}$ International Conference of Representation Disciplines Teachers. Milano: FrancoAngeli, 225-244. 